\title{
A PROPOSAL OF CURRICULAR GOALS AND OBJECTIVES FOR TEACHING STUDENT SKILLS TO CREATE THE TRADITIONAL ART OF SOUTH-SULAWESI AS A PART OF THE MUATAN-LOKAL PROGRAM IN THE KUMALA ELEMENTARY SCHOOL OF UJUNG PANDANG, INDONESIA
}

\author{
Sofyan Salam
}

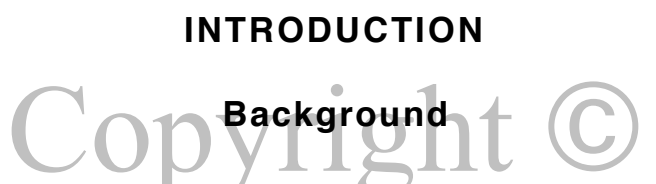

One of the most significant characteristics of Indonesia as a nation is its cultural diversity. Indonesia consists of no less than 13,667 large and small islands and has over 300 ethnic groups and more than 250 languages (Vreeland 62,83 ). This fact, becomes a major challenge for the Indonesian government in providing a national education for Indonesian people that does not alienate them from their cultural roots.

In 1987, the Indonesian Ministry of Education and Culture introduced a new program, called muatan-lokal curriculum to be implemented in schools throughout the nation (Ansyar 65). The muatan-lokal curriculum may be translated in English as "local-content" curriculum or "locally-oriented" curriculum. The muatan-lokal curriculum provides the schools with a wider opportunity to present subjects relevant to local schools' needs and environment. The muatan-lokal curriculum may contain subjects such as animal husbandry, vegetable growing, folklore, customs, or traditional arts/crafts (Sulsel, Kurikulum Pendidikan 3).

The need for offering an educational program relevant to the needs of local schools was further emphasized when the Indonesian government and People's Representative Council passed the Indonesian Convention number $2 / 1989$ on national education. Article 38 of the Convention requires all schools in Indonesia to implement both a standardized national curriculum and a regional or muatan-lokal curriculum (Depdikbud, Undang 27).

To facilitate the implementation of the muatan-lokal curriculum, the Indonesian Ministry of Education and Culture included the muatan-lokal program in the elementary and high school curriculums of 1994.

Since the Indonesian Ministry of Education and Culture in Jakarta, the capital of Republic of Indonesia, provides only a general implementation guideline for the muatan-lokal curriculum, it is the task of the Regional Office of the Ministry of Education and Culture as well as schools/communities in provinces to decide and to develop their own muatan-lokal curriculums. 
The Indonesian Ministry of Education and Culture realized that the lack of experienced personnel needed to develop such a new program and the limited number of supporting facilities such as books and other written materials in most Indonesian schools could become a major obstacle in implementing the muatan-lokal curriculum (Ansyar 100), and therefore, it does not strictly enforce the implementation of the curriculum. Schools which have not been ready to implement the muatan-lokal curriculum are given time to prepare themselves. In the guidelines of the development of the muatan-lokal curriculum published by the Indonesian Ministry of Education and Culture, it is stated that the implementation of the muatan-lokal curriculum depends on the readiness of each school in term of the availability of curriculum materials and supporting equipment as well as teachers that are able to carry-out the program (Depdikbud, Pedoman Pengembangan 2).

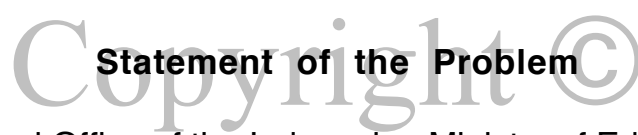

The Regional Office of the Indonesian Ministry of Education and Culture of South-Sulawesi Province recommended that traditional art to be taught as a part of the muatan-lokal curriculum in elementary schools with the general (provincial level) goals as follows: (1) to preserve, explore, and revitalize the traditional art of South-Sulawesi in order to promote Indonesian national identity; (2) to develop student knowledge, attitudes, and skills in the traditional art of South-Sulawesi; and (3) to prepare students with knowledge, attitudes and skills needed to enter high school (Sulse 7). These goals are very broad and therefore need to be formulated into more specific statements, known as curricular goals and objectives to make them operational (Zais 306).

To take part in the promotion of teaching traditional art as a part of the muatan-lokal curriculum, I will conduct a research to produce a proposal concerning curricular goals and objectives for teaching student skills to create the traditional art of South-Sulawesi in the Kumala elementary school of Ujung Pandang, South-Sulawesi's provincial capital. Selecting the focus (curricular goals and objectives for teaching student skills to create the traditional art of South-Sulawesi) and the site (the Kumala elementary school) are practical choices that focus the scope of this inquiry.

The problem of producing the proposal is: how to develop curricular goals and objectives that are important (in relation to the idea of preserving, exploring and revitalizing the traditional art of South-Sulawesi), appropriate (in relation to the prospective students), and practical (in relation to the school system and facility). Embedded in this problem are questions about how far the traditional elements (of the South-Sulawesi traditional art) can be maintained or have to be sacrificed to meet the changing need of the society; and what are the obstacles that might inhibit the implementation of the proposed curricular goals and objectives, and how to overcome these obstacles? This study deals with the way the respondents cope with the problem. 
The questions of this study may be formulated as follows:

(1) What should be the curricular goals and objectives for teaching student skills to create the traditional art of South-Sulawesi as a part of the muatan-lokal program in the Kumala elementary school of Ujung Pandang, Indonesia?; and objectives?

(2) What is the prospect for implementation of these curricular goals and

\section{Significance of the Study}

The product of this study will be a proposal concerning curricular goals and objectives for teaching student skills to create the traditional art of SouthSulawesi as a part of the muatan-lokal curriculum in the Kumala Elementary School of Ujung Pandang, Indonesia. The proposal will include an introduction, a rationale, curricular goal and objective statements, and a recommendation that can be used as reference for teachers at the Kumala Elementary School in developing muatan-loka/ programs for traditional art subjects. The proposal may also serve as reference for anyone who is interested in developing such a muatan-lokal program in other schools, particularly in schools that share similar characteristics with the Kumala Elementary School.

The proposal may also provide information that is valuable for individuals or institutions involved in educational affairs such as university professors, administrators, educational planners, teacher preparation institutions, or cultural centers.

\section{Limitations of the Study}

Certain limitations will exist in this study. These limitations include:

(1) The proposal produced by this study will be applicable only to the Kumala Elementary School of Ujung Pandang or schools that share similar characteristics with the Kumala Elementary School.

(2) The findings concerning the importance, appropriateness and practicability of the curricular goals and objectives included in the proposal will be based only on the opinions expressed by the respondents of this study.

(3) Data obtained from the questionnaires and the follow-up interviews used in this study would be useful only to the extent that respondents expressed their opinions honestly.

(4) Due to time and financial constraints, I will not be able to visit Indonesia to personally organize activities pertaining to this study. To overcome this limitation I will ask the chairperson of the Art Education Department of FPBS IKIP Ujung Pandang to assign faculty members and other volunteers who have research experiences to take over the task. 


\section{Definition of Terms}

(1) Curricular goals: statements specifying outcomes to be achieved by students after completing a long-range (one year or six year) educational program. In Indonesia, this term is known as tujuan-tujuan pembelajaran umum.

(2) Curricular objectives: statements specifying immediate outcomes to be achieved by students after completing a classroom instruction. In Indonesia, this term is known as tujuan-tujuan pembelajaran khusus.

(3) Elementary school: the first level of Indonesian formal education offering a six-year program to be attended by children who have finished kindergarten programs or those who are already seven years old.

(4) The Kumala Elementary School: an elementary school located in the southern part of Ujung Pandang, the capital of South-Sulawesi province.

According to its August 1997 report, the school has 234 students with 8 teachers.

(5) Muatan-lokal curriculum: an educational program to present subjects relevant to the local schools' needs and environment.

(6) South-Sulawesi: an Indonesian provincial administration which lies in the south-western peninsula of Sulawesi (formerly Celebes) Island.

(7) The traditional art of South-Sulawesi: functional objects created artistically, using both techniques and ornamental motifs that belong to ethnic groups of South-Sulawesi.

\section{METHODOLOGY}

\section{Conducting Literature Search}

I will search concepts, models, rules, or historical perspectives relating to art in Indonesian society, South-Sulawesi traditional arts, and the goals for teaching art in elementary schools in general, and traditional art in particular. The purpose of this literature search is to develop my preliminary statement of the proposed curricular goals and objectives. A major segment in the methodical decision process will be to start off with a preliminary statement that a panel of experts could consider, and improve.

\section{Determining the Respondents}

I will employ the purposive sampling technique in this study by selecting respondents on the basis of their relevance to the study question. Since the purpose of this study is to produce a proposal concerning curricular goals and objectives for teaching student skills to create the traditional art of SouthSulawesi province as a part of the muatan-lokal in the Kumala elementary school of Ujung Pandang, the respondents for this study will be people who have professional experiences or interests with the study question. 
I will contact four people: the principal of the Kumala Elementary School, the chairperson of the Art Education Department of FPBS IKIP Ujung Pandang, a high school art teacher at Ujung Pandang, and an Ujung Pandang artist, to ask their participation in the selection of one or more representatives of the following groups: (1) the Kumala elementary school teachers; (2) the Parent-Teacher Association members for the Kumala Elementary School; (3) Ujung Pandang high school art teachers; (4) faculty members of the Art Education Department of FPBS IKIP Ujung Pandang; (5) museum directors/staff; (6) anthropologists/ historians; (7) Staff of the Regional Office of the Ministry of Education and Culture of South-Sulawesi Province; and Ujung Pandang artists.

\section{The Collection of the Data}

I will collect the data to answer the research questions in two stages: first, by using questionnaires, and second by conducting follow-up interviews.

\section{First Stage}

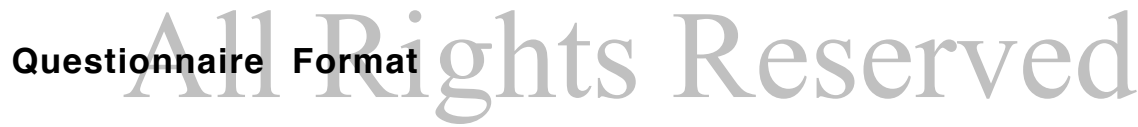

The questionnaires will be supplemented with a cover letter explaining the purpose of this study; and an appendix containing a brief description of the nature of the traditional art of South-sulawesi and illustrations of South-Sulawesi traditional art forms mentioned in the questionnaires.

The questionnaires will present the author's preliminary statement of the proposed curricular goals and objectives to be rated by the respondents in terms of their importance (in relation to the idea of preserving, exploring, and revitalizing the traditional art of South-sulawesi), appropriateness (in relation to the prospective students), and their practicality/achievability (in relation to the school system and facility). The questionnaires also will ask the respondents to give written comments concerning the proposed curricular goals and objectives.

Three types of questionnaire will be used in this study. (1) The questionnaire A for non-teacher respondents: this questionnaire will ask the non-teacher respondents to rate the preliminary form of the proposed curricular goals and objectives in term of their importance and their appropriateness. The questionnaire will also ask the respondents to provide their reasons for the rating.

(2) The questionnaire B for teacher respondents: this questionnaire will also present the author's preliminary statement of the proposed curricular goals and objectives to be rated and commented as in the questionnaire A. In addition, the questionnaire $B$ will ask the teacher respondents to rate and comment on the practicality/ achievability of the proposed curricular goals and objectives.

(3) The questionnaire $C$ for selected teacher respondents: this questionnaire will be more elaborated than the questionnaire A or B, as it will ask the respondents to provide more specific comments concerning the author's 
preliminary statement of the proposed curricular goals and objectives. The questionnaires will be given in English and Indonesian versions.

\section{Questionnaire Design}

After conducting a review of questionnaire design methods, I will construct the initial drafts of the questionnaires. The drafts will be critiqued by experts at the College of Education and the Evaluation and Examination Service of the University of lowa. Comments given by these experts will be used to revise the first drafts.

The Indonesian version of the revised questionnaires were tried-out with a small group of people (about 7 persons) who represent the target respondents but will not be part of the sample, to determine the clarity and the usefulness of the questionnaires.

The questionnaire try-out will be conducted in two phases: first, the try-out respondents will be asked to respond to the questionnaire items; and second, the respondents will be asked to give comments regarding the directions, the items, and the appendix of the questionnaires. Feedback gathered during the try-out will be used to revise the questionnaires. The revised questionnaires will be shown again to experts to ensure effective wording of the revised questionnaire items.

\section{The Distribution of the Questionnaires}

Before distributing the questionnaires, I will ask the head of the SouthSulawesi Province Office of Education and Culture issued permission to me to collect data for this study.

Upon getting the permission, I will send letters to the principal of the Kumala Elementary School and to the chairperson of the Art Education Department of FPBS IKIP Ujung Pandang, to officially ask them to participate in this study and to inform the prospective respondents, selected earlier, about the data collection of this study.

I will mail the Indonesian version of the questionnaires $A, B$, and $C$ to the chairperson of the Art Education Department of FPBS IKIP Ujung Pandang. He, in turn, will distribute the questionnaires to the target respondents. Also, a copy of the research proposal, for use as reference, will be mailed at the Art Education Department.

\section{Second Stage}

A follow-up investigation to get a more complete understanding about the respondents' written opinion will be conducted by interviewing a sample of respondents. I will personally interview the respondents who have telephone at homes. I will ask a faculty member of the Art Education Department to interview the others. 


\section{The Analysis and Synthesis of the Data}

The opinions and suggestions given by the respondents regarding my preliminary statement of the proposed curricular goals and objectives will be used to determine which goals or objectives should be maintained, revised, or abandoned. At the end, I will produce a proposal consisting of a rationale, curricular goal-and-objective statements, and a recommendation for the user.

\section{REFERENCES}

Ansyar, Mohd and H. Nurtain. Pengembangan dan Innovasi Kurikulum. Jakarta: Dikti, 1991/1992.

Badrogi, Tigor. Art of Indonesia. Greenwich, CT: New York Graphic Society, 1972.

Davis, Donald Jack. "Human Behavior: Its Implications for Curriculum Development in Art." Curricular Considerations for Visual Arts Education: Rationale,Development, and Evaluation. Ed. George W. Hardiman and Theodore Zernich. Champaign, IL: Stipes, 1974. 174-184.

Depdikbud. Undang-Undang Republik Indonesia Nomor 2 Tahun 1989 tentang Sistem Pendidikan Nasional Beserta Penjelasan. Jakarta: Balai Pustaka, 1989.

Pedoman Guru Seni Rupa Sekolah Dasar. Jakarta: Depdikbud, 1983.

. Pedoman Pengembangan Kurikulum Muatan Lokal. Jakarta: Balitbang Depdikbud, 1993.

Ecker, David W. "The Structure of Affect in the Art Curriculum." Curricular Considerations for Visual Arts Education:Rationale, Development, and Evaluation. Ed. George W Hardiman and Theodore Zernich. Champaign, IL: Stipes, 1974. 165-173.

Eisner, Elliot W. "Do Behavioral Objectives and Accountability Have a Place in Art Education." Curricular Considerations for Visual Arts Education: Rationale, Development, and Evaluation. Ed. George W. Hardiman and Theodore Zernich. Champaign, IL: Stipes, 1974. 185-194.

Educating Artistic Vision. Reston, VA: NAEA, 1997

Mager, Robert F. Preparing Instructional Objectives. Belmont: David S. Lake, 1984. 
Posner, George J., and Alan N. Rudnitsky. Course Design:A Guide to Curriculum Development for Teachers. New York: Longman, 1994.

Smith, Earl P. "Toward a Taxonomy of Objectives for ArtEducation." Curricular Considerations for Visual Arts Education: Rationale, Development, and Evaluation. Ed. George W. Hardiman and Theodore Zernich. Champaign, IL: Stipes, 1974. 153-164.

Soebadio, Haryati. Cultural Policy in Indonesia. Paris: Unesco Press, 1985.

Sulsel, Kanwil Depdikbud. Kurikulum Pendidikan Dasar: Acuan Pengembangan Kurikulum Muatan Lokal Propinsi Sulawesi Selatan. Ujung Pandang: Kanwil Defdikbud, 1004.

. Kurikulum Muatan Lokal Pendidikan Dasar; Garis-garis Besar Program Pengajaran. Ujung Pandang: Kanwil Depdikbud, 1994.

Zais, Robert S. Curriculum Principles and Foundations. New York:

Thomas Y. Crowell, 1976.

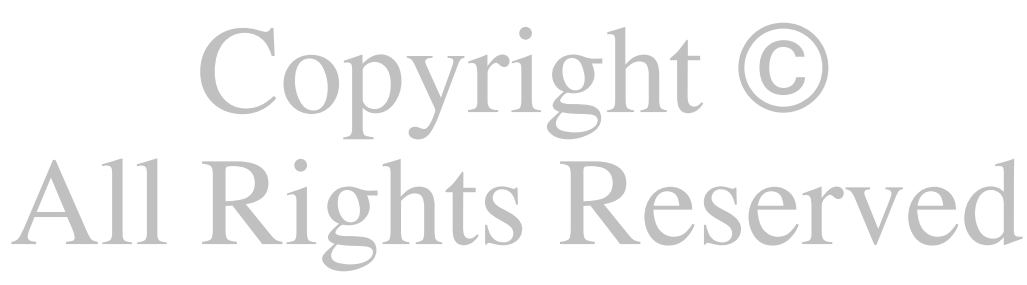

